\title{
OTONOMI DAERAH DAN KORUPSI
}

Oleh:

\author{
NORSANTI
}

\begin{abstract}
The regional autonomy policies generally appear because of bad implementation from government machine. It does not go from local society and small society needs. The regional disatisfaction to the government also is encouraged by massively exploitation of natural resources that occure in regoins that have many natural resources, but there is not optimalization of holding development in the region. However, in the fact, since the regional autonomy is applied in 1999 until now the wishes of society in order to get optimalization of holding development in a region are not implemented even, the moving of corruption is occurred from central to regions.

Islam has an unique method to prevent corruption in a region. In Islamic government (khilafah), there is not regional autonomy because the from of islamic state is a united state. A governor (wali) is elected by khalifah directly, it also occures in smaller regions. Wali is not elected by citizens and DPRD because there is not DPRD in khilafah state. The directly pointing makes candidates of governor do not need confuse to prepare a lot of donation for campaign or bribe citizens in order to choose them until they do not need fund in jection from others (enterpreneur). In addition, the moneter policies in khilafah system also follow sentralization principle, that very different with fiscal desentralization in the regional autonomy in khilafah system, donation from the whole regions is pulled by central region to distribute to each regions based their needs. It doesn't distribute based on the amount of incomes.
\end{abstract}

Key words: regional autonomy, corruption

\section{Pendahuluan}

Sejak diterapkannya UU No. 29 tahun 1999 yang direvisi menjadi UU No. 32 tahun 2004 tentang Pemerintahan Daerah, telah terjadi pergeseran pelaksanaan pemerintahan di Indonesia yang semula menganut asas sentralisasi menjadi desentralisasi. Dengan penerapan sistem desentralisasi ini maka pemerintah daerah mempunyai wewenang untuk mengatur dan mengurus urusan pemerintahan dan kepentingan masyarakat setempat menurut prakarsa sendiri berdasarkan aspirasi masyarakat sesuai dengan peraturan perundangundangan.

Hoessein (seperti yang dikutip oleh Muluk, 2007: 9) mengungkapkan bahwa desentralisasi mencakup dua elemen pokok. Pertama, pembentukan daerah otonom, dan kedua, penyerahan urusan pemerintahan kepada daerah otonom tersebut. Kewenangan pemerintahan daerah untuk mengatur dan 
mengurus rumah tangga daerahnya sendiri itulah yang disebut dengan otonomi daerah.

Munculnya wacana kebijakan otonomi daerah tidaklah muncul begitu saja. Secara umum kebijakan ini muncul karena buruknya pelaksanaan mesin pemerintahan yang tidak berangkat dari kebutuhan masyarakat local (local needs) dan rakyat kecil. Kebijakan pemerintah yang cenderung sentralistik hanya berpihak pada segelintir orang terutama elit politis dan kapitalis. Selain itu, juga terdapat kesenjangan dan ketimpangan yang cukup besar antara pembangunan yang terjadi di daerah dengan pembangunan yang dilaksanakan di kota-kota besar.

Ketidakpuasan daerah terhadap pemerintahan juga didorong oleh massifnya eksploitasi sumber daya alam yang terjadi di daerah-daerah yang kaya akan sumber daya alam. Eksploitasi kekayaan alam di daerah kemudian tidak berbanding lurus dengan optimalisasi pelaksanaan pembangunan di daerah tersebut. Hal inilah yang mendorong lahirnya tuntutan masyarakat yang mengingingkan kewenangan untuk mengatur dan mengurus daerah sendiri dan menjadi latar belakang otonomi daerah di Indonesia.

Tujuan pemberian otonomi kepada daerah adalah mencapai efisiensi dan efektivitas dalam pelayanan kepada masyarakat. Hal ini berarti bahwa daerah berkewajiban untuk menumbuhkembangkan daerah dalam berbagai bidang, meningkatkan pelayanan kepada masyarakat, menumbuhkan kemandirian daerah dan meningkatkan daya saing daerah dalam proses pertumbuhan. (Widjaja, 2005: 17)

Namun secara faktual, sejak otonomi daerah diterapkan tahun 1999 hingga saat ini harapan masyarakat agar tercapai efisiensi dan efektivitas dalam pelayanan kepada masyarakat belum terwujud. Hal ini terbukti dari hasil evaluasi Kementerian Dalam Negeri (Kemendagri) terhadap 57 daerah pemekaran baru selama 1999 - 2010 menunjukkan sebanyak 78\% gagal menyejahterakan warga. Evaluasi yang dilakukan pada 2011 itu terutama difokuskan pada usaha pemerintah daerah meningkatkan kesejahteraan dan kualitas layanan publik bagi masyarakat di wilayah hasil pemekaran. (mediaindonesia.com, 30 Agustus 2012)

Ketidakmampuan pemerintah daerah meningkatkan pelayanan kepada masyarakat sekitarnya diperparah lagi dengan merebaknya fenomena korupsi di daerah. Fenomena inilah yang sejak lama menjadi kekhawatiran banyak kalangan berkaitan dengan implementasi otonomi daerah yaitu bergesernya praktik korupsi dari pusat ke daerah. Sinyalemen ini menjadi semakin beralasan ketika terbukti bahwa banyak pejabat publik yang masih mempunyai kebiasaan menghambur-hamburkan uang rakyat untuk kepentingan pribadi dan kelompoknya. Berdasarkan data Kementrian Dalam negeri terungkap bahwa sebanyak 318 orang dari total 524 orang kepala daerah dan wakil kepala daerah tersangkut dengan kasus korupsi dan sebagian besar diantaranya sudah ditahan. (republika online, 14 februari 2014)

Maraknya korupsi di daerah akan semakin menjauhkan tercapainya efisiensi dan efektivitas pelayanan pemerintah daerah. Fakta terbaru adalah 
kasus korupsi yang melibatkan gubernur Banten Ratu Atut Chosiyah dan keluarganya. Untuk memuluskan aksi korupsinya gubernur Banten membangun politik dengan mengangkat keluarganya pada posisi strategis yang lebih kita kenal dengan politik dinasti. Separuh dari 8 kota atau kabupaten di Propinsi Banten dikuasai keluarga besar Chasan Sochib, ayah Ratu Atut, Gubernur Banten sekarang. Anggota keluarga besar ini menduduki berbagai jabatan baik di DPRD I, DPRD II, jabatan eksekutif mulai Gubernur, walikota atau wakilnya, bupati atau wakilnya dan jabatan-jabatan struktural di pemerintahan lainnya. Oleh karena itu tidak mengherankan kalau puluhan miliar rupiah dalam bentuk dana hibah dari Anggaran Pendapatan dan Belanja Daerah (APBD) Provinsi Banten tahun anggaran 2012 mengalir ke organisasi, lembaga dan yayasan yang dipimpin oleh adik, anak, dan menantu gubernur banten. Namun ternyata politik dinasti yang terjadi di Banten bukan satusatunya kasus di negeri ini, menurut Menteri Dalam Negeri Gamawan Fauzi ada 57 kepala daerah dan wakil kepala daerah yang terlibat politik dinasti (merdeka.com, Oktober 2013)

. Gurita politik terjadi untuk mempertahankan kekuasaan agar tidak keluar dari link mereka. Selanjutnya kekuasaan itu dijadikan alat untuk mengamankan diri dan kepentingan. Jika bukan untuk menumpuk kekayaan, maka yang hampir bisa dipastikan adalah untuk mengembalikan modal yang dikeluarkan selama proses politik sebelumnya dan mengumpulkan biaya bagi proses politik ke depan, selain untuk balas budi kepada para cukong yang secara langsung maupun tidak langsung, memodali proses politik yang dijalani. Oleh karena itu, peneliti senior Indonesian Public Institute (IPI), Karyono Wibowo menyatakan bahwa dinasti politik sangat berbahaya dan mengancam asas keadilan di negeri ini.

\section{Metode Penelitian}

Metode penelitian yang digunakan dalam tulisan ini adalah studi kepustakaan. Menurut M. Nazir, studi kepustakaan adalah teknik pengumpulan data dengan mengadakan studi penelaahan terhadap buku-buku, literatur-literatur, catatan-catatan, dan laporan-laporan yang ada hubungannya dengan masalah yang dipecahkan. Sumber-sumber kepustakaan dapat diperoleh dari: buku, jurnal, majalah, hasil-hasil penelitian (tesis dan disertasi), dan sumber-sumber lainnya yang sesuai (internet, koran dll). Dalam tulisan ini sumber kepustakaan yang dijadikan rujukan berasal dari buku (tentang otonomi daerah dan pemerintahan Islam) serta tulisan-tulisan dari para ahli yang dimuat di berbagai media massa yang berkaitan dengan objek kajian.

\section{Hasil dan Pembahasan}

\section{Konsep Otonomi Daerah}

Dalam bahasa Yunani, otonomi berasal dari kata autos dan namos. Autos berarti sendiri dan namos berarti aturan atau undang-undang, sehingga dapat diartikan sebagai kewenangan untuk mengatur sendiri atau kewenangan untuk membuat aturan guna mengurus rumah tangga sendiri. Sedangkan 
daerah adalah kesatuan masyarakat hukum yang mempunyai batas-batas wilayah.

Otonomi daerah menurut Vincent Lemius, adalah Kebebasan (kewenangan) untuk mengambil atau membuat suatu keputusan politik maupun administrasi sesuai dengan peraturan perundang-undangan. Di dalam otonomi daerah terdapat kebebasan yang dimiliki oleh pemerintah daerah untuk menentukan apa yang menjadi kebutuhan daerah namun apa yang menjadi kebutuhan daerah tersebut senantiasa harus disesuaikan dengan kepentingan nasional sebagaimana yang telah diatur dalam peraturan perundang-undangan yang lebih tinggi.

HAW Widjaja (2005: 25) mendefinisikan otonomi daerah sebagai kewenangan daerah otonom untuk mengatur dan mengurus kepentingan masyarakat setempat. Kewenangan tersebut meliputi kewenangan politik, urusan daerah dan pengelolaan keuangan.

Buyung (2002: 8.6) menyatakan bahwa otonomi daerah adalah hak, wewenang, kewajiban daerah untuk mengatur dan mengurus rumah tangganya sendiri sesuai dengan peraturan perundang-undangan yang berlaku.

Selain menurut para ahli, konsep otonomi daerah juga dapat diambil dari Undang-Undang Nomor 32 Tahun 2004 tentang Pemerintahan Daerah yaitu hak, wewenang, dan kewajiban daerah otonom untuk mengatur dan mengurus sendiri urusan pemerintahan dan kepentingan masyarakat setempat sesuai dengan peraturan perundang-undangan.

Berdasarkan beberapa pengertian di atas, maka dapat disimpulkan bahwa otonomi daerah adalah kewenangan atau kebebasan yang dimiliki oleh pemerintah daerah untuk mengurus atau mengatur daerahnya sendiri.

Menurut HAW Widjaja (2003: 33) secara teoritis, kata kunci dalam otonomi daerah berarti juga desentralisasi. Desentralisasi adalah penyerahan wewenang pemerintahan oleh pemerintah pusat kepada daerah otonom.

Desentralisasi, baik dalam bentuk dekonsentrasi, delegasi maupun devolusi terjadi dalam berbagai bidang, tidak hanya politik tetapi juga ekonomi. Jika desentralisasi politik dilambangkan dengan kemandirian dalam pemilihan aparatur pemerintahan untuk tingkat desentralisasi tertentu, seperti pemilihan bupati/walikota. Adapun desentralisasi ekonomi diartikan sebagai kemandirian dalam pengaturan fiskal (keuangan) daerah yang meliputi alokasi pengeluaran dan mobilisasi penerimaan daerah. (Suhadak dan Nugroho, 2007: 119)

\section{Implementasi Otonomi Daerah}

Implementasi (pelaksanaan) otonomi daerah meniscayakan adanya kewenangan pemerintah daerah untuk mengatur daerahnya sendiri baik terkait dengan urusan politik maupun ekonomi. Kemandirian daerah pada bidang politik berkaitan dengan kewenangan daerah untuk melakukan pemilihan aparatur pemerintah termasuk kepala daerah.

Menurut Khairul Muluk (2007: 137), perubahan penting yang terkandung dalam UU No. 32 Tahun 2004 tentang pemerintahan daerah adalah penentuan 
kepala daerah yang dilakukan melalui cara pemilihan langsung oleh masyarakat tidak lagi melalui mekanisme pemilihan oleh DPRD. Dengan pemilihan langsung ini diharapkan kepala daerah yang terpilih adalah orang yang benar-benar sesuai dengan keinginan masyarakat. Pilkada secara langsung pertama kali diselenggarakan pada bulan juni 2005.

Pada awalnya pemilihan kepala daerah secara langsung diharapkan dapat memenuhi aspirasi masyarakat, namun kini pilkada justru menjadi persoalan. Diantara persoalan itu adalah persoalan besarnya biaya penyelenggaraan pilkada dan korupsi kepala daerah terpilih selama menjabat. Kemendagri mencatat, ada 290 kepala daerah/bupati/walikota yang terlibat dalam korupsi mulai dari yang masih berstatus tersangka hingga terpidana.

Besarnya biaya penyelenggaraan pilkada juga menjadi persoalan tersendiri bagi daerah. Menurut peneliti Seknas Fitra, Yuna Farhan rata-rata biaya pemilukada Rp 25 milyar per kabupaten/kota dan Rp 100 miliar per provinsi (satu putaran) maka dana yang dibutuhkan dari APBN untuk pemilu kada sekitar Rp 17 trilyun atau 4,2 trilyun setahun selama empat tahun. Bagi daerah yang mengalami keterbatasan dana, hanya untuk sekedar membiayai penyelenggaraan pilkada mereka terpaksa mengurangi belanja publik seperti pendidikan dan kesehatan. Jika demikian, belum lagi kepala daerah terpilih hak rakyat dalam kesehatan dan pendidikan sudah terampas.

Selain itu, pemerintah daerah juga diberikan kewenangan untuk mengatur urusan ekonomi di daerahnya yang berkaitan dengan fiskal (keuangan) yang lebih dikenal dengan desentralisasi fiskal. Desentralisasi fiskal pada dasarnya berkaitan dengan dua hal pokok yaitu kemandirian daerah memutuskan pengeluaran guna menyelenggarakan layanan publik dan pembangunan serta kemandirian daerah memperoleh pendapatan guna membiayai pengeluaran itu.

Pengelolaan keuangan daerah di Indonesia dapat ditelusuri dari UU No.32 dan 33 tahun 2004. Disebutkan dalam peraturan tersebut bahwa sumber penerimaan (pendapatan) daerah dalam pelaksanaan otonomi daerah terdiri atas pendapatan daerah dan pembiayaan. Adapun pengeluaran (belanja) daerah meliputi semua pengeluaran dari rekening kas umum daerah untuk membiayai belanja aparatur daerah dan belanja pelayanan publik. Semua penerimaan dan pengeluaran daerah dituangkan dalam Anggaran Pendapatan dan Belanja Daerah (APBD) yang dirancang pemerintah daerah bersama dengan DPRD untuk satu tahun.

Menurut Suhadak dan Nugroho ( 2007: 141) dengan adanya kemandirian daerah dalam pengelolaan keuangan maka diharapkan akan mendorong tata kelola pemerintahan menuju pemerintahan yang baik (Good Governance) dan membentuk tata kelola pemerintahan yang bersih (Clean Government).

Namun kenyataannya desentralisasi fiskal ini menimbulkan banyak masalah terkait pengelolaan keuangan daerah. Pada tahun 2010 saja ICW (Indonesia Cooruption Watch), merilis data yang menunjukkan bahwa salah satu penyumbang kerugian negara adalah korupsi keuangan daerah. Korupsi yang terjadi di daerah tersebut, terutama dilakukan oleh oknum DPRD dan Kepala Daerah. Penyebab dari tingginya angka ketidakwajaran atas laporan 
keuangan pemerintah daerah tersebut adalah rendahnya akuntabilitas, penyimpangan anggaran daerah, rendahnya daya serap anggaran dan rendahnya disiplin atas pengelolaan anggaran.

Berdasarkan data di atas tergambar bahwa pelaksanaan otonomi daerah bukannya membawa berkah bagi rakyat di daerah tapi segudang masalah kini datang menghampiri, diantaranya adalah besarnya penyelenggaran biaya pilkada yang terkadang diambil dari anggaran belanja pelayanan publik, penyelewengan pengelolaan keuangan daerah yang di ikuti dengan tindakan korupsi yang dilakukan oleh pejabat di daerah.

\section{Otonomi Daerah : Menyuburkan Korupsi Di Daerah}

Dalam pidato pengukuhan Prof. Wihana Kirana Jaya, Msoc.Sc., Ph.D. sebagai Guru Besar dalam Ilmu Ekonomi di Universitas Gadjah Mada (2010), disebutkan bahwa sejumlah studi yang dilakukan terhadap negara maju dan berkembang menunjukkan bahwa penyelenggaraan desentralisasi dan otonomi daerah di satu sisi telah mendorong terciptanya akuntabilitas anggaran, namun di sisi lain juga membuka peluang yang sangat besar bagi terjadinya korupsi, kolusi dan nepotisme serta memungkinkan terjadinya kontrol yang kuat dari para elit politik di tingkat lokal (daerah). Mencermati pernyataan beliau tersebut semakin menguatkan dugaan bahwa otonomi daerah semakin membuka peluang terjadinya korupsi, kolusi dan nepotisme di daerah.

Di Indonesia trend korupsi di daerah juga semakin meningkat seiring semakin gencarnya penerapan otonomi daerah di negeri ini. Menurut data, selama tahun 2010 dari 244 pemilu kada ada 148 kepala daerah yang terpilih tersangkut pidana korupsi. Tahun berikutnya yaitu 2011 terjadi peningkatan dimana menurut penuturan Mendagri, Gamawan Fauzi ada 155 kepala daerah yang tersangkut masalah hukum, 17 orang di antaranya adalah gubernur. Selanjutnya tahun 2013 menurut data Kementrian Dalam negeri terungkap bahwa ada 290 kepala daerah/bupati/walikota yang terlibat dalam korupsi mulai dari yang masih berstatus tersangka hingga terpidana. (media ummat, edisi 99 tahun 2013)

Semakin meningkatnya jumlah kepala daerah yang tersangkut kasus korupsi semakin menguatkan dugaan bahwa otonomi daerah membawa dampak negatif bagi daerah berupa merebaknya korupsi yang dilakukan oleh pejabat publik. Penyerahan kewenangan bagi daerah untuk mengelola keuangan rumah tangganya sendiri menjadikan peluang terjadinya korupsi oleh pejabat daerah semakin besar. Hal ini dikarenakan penyusunan APBD diserahkan kepada pemerintah daerah bersama dengan DPRD. Adapun mekanismenya adalah sebagai berikut: pertama-tama RAPBD disusun oleh pemerintah daerah, setelah RAPBD selesai disusun maka akan diajukan ke DPRD dan dibahas oleh DPRD dengan pemerintah daerah, setelah disetujui baru APBD disahkan dalam bentuk peraturan daerah.

Karena mekanismenya seperti itu, maka penerimaan dan pengeluaran dalam satu tahun anggaran, termasuk alokasi masing-masing penerimaan dan pengeluaran APBD tersebut bersifat fixed. Konsekuensinya, setelah APBD 
disahkan maka besaran penerimaan dan pengeluaran tersebut juga harus fixed, tidak boleh kurang atau lebih.

Hal itu akan mebawa dua konsekuensi: pertama, terkait dengan penerimaan yang biasanya mengacu pada asumsi dolar sebagai patokan dan tingkat inflasi. Jika dalam rentang satu tahun tersebut asumsi dolar dan tingkat inflasinya berubah, maka APBD pun akan direvisi sehingga ada istilah APBD-P (Anggaran Pendapatan dan Belanja Daerah - Perubahan). Kedua, terkait dengan pengeluaran yang juga harus tetap (fixed), maka alokasi anggaran tersebut juga harus habis dan terserap. Namun, pada faktanya tidak semua anggaran belanja tersebut habis dan bisa diserap semua. Pada titik inilah, seringkali dilakukan berbagai cara agar anggaran tersebut dihabiskan karena ada ketakutan kalau anggaran tersebut tidak habis maka anggaran belanja tahun berikutnya akan dikurangi.

Oleh karena itu, tidak mengherankan kalau masih banyak pejabat publik yang mempunyai kebiasaan menghambur-hamburkan uang rakyat untuk piknik ke luar negeri dengan alasan studi banding untuk menghabiskan sisa anggaran. Sumber praktik korupsi lain yang masih berlangsung terjadi pada proses pengadaan barang-barang dan jasa daerah (procurement). Seringkali terjadi harga sebuah item barang dianggarkan jauh lebih besar dari harga pasar. Kolusi antara bagian pengadaan dan rekanan sudah menjadi hal yang jamak. Pemberian fasilitas yang berlebihan kepada pejabat daerah juga merupakan bukti ketidakarifan pemerintah daerah dalam mengelola keuangan daerah.

Selain itu menurut Dirjen Otonomi Daerah Kementrian Dalam Negeri, Prof. Dr. Djohermansyah Djohan, akar masalah merebaknya korupsi di daerah adalah terjebaknya kepala daerah dalam jebakan korupsi karena dilakukannya pemilihan kepala daerah secara langsung yang membutuhkan biaya yang besar. Biaya tinggi dalam pemilihan membuat calon kepala daerah harus mengeluarkan uang dari kantong sendiri atau mencari sumbangan dari sektor swasta. Akibatnya, setelah calon terpilih, dia sibuk mengembalikan uang yang dikeluarkan dalam pemilihan dengan jalan korupsi karena uang gajinya tidak memadai untuk menutupi biaya tersebut. Kepala daerah juga sering memuluskankan proyek pengusaha-pengusaha bermasalah untuk mengembalikan investasi yang diberikan pihak swasta yang membantunya.

\section{Metode Islam Dalam Mencegah Terjadinya Korupsi Pejabat Di Daerah}

Korupsi di Indonesia agaknya telah menjadi persoalan yang amat kronis. Ibarat penyakit, korupsi telah menyebar luas ke segenap penjuru negeri dengan jumlah yang cenderung semakin meningkat dari tahun ke tahun serta modus yang semakin beragam. Hasil riset berbagai lembaga menunjukkan bahwa tingkat korupsi di negeri yang penduduknya mayoritas muslim ini termasuk yang paling tinggi di dunia.

Berbagai upaya sudah dilakukan untuk memberantas korupsi diantaranya dengan merumuskan berbagai kebijakan dan membentuk lembaga anti korupsi seperti KPK. Namun upaya tersebut belum membuahkan hasil malah yang terjadi korupsi semakin menyebar bukan hanya di tingkat pusat tapi juga 
daerah. Kebijakan Otonomi daerah yang mengatur pemilihan kepala daerah secara langsung dan pemberian otonomi luas kepada daerah dalam hal pengelolaan keuangan daerah diduga kuat menjadi penyebab utama merebaknya fenomena korupsi di daerah.

Dalam pemerintahan Islam (khilafah) tidak mengenal otonomi daerah karena bentuk Negara Islam adalah Negara kesatuan bukan negara federasi atau federasi semu semacam otonomi daerah. Wilayah kekuasaan Negara Islam adalah wilayah yang satu. Hal ini ditegaskan dalam banyak hadist Nabi, diantaranya: Dulu Bani Israel diurusi dan dipelihara oleh para nabi. Setiap kali seorang nabi meninggal digantikan oleh nabi yang lain.Akan tetapi, sesungguhnya tidak ada nabi sesudahku, yang akan ada adalah para khalifah, dan mereka banyak." Para sahabat bertanya, Lalu apa yang engkau perintahkan kepada kami? Nabi bersabda, Penuhilah baiat yang pertama, yang pertama saja, berikanlah kepada mereka hak mereka. Sesungguhnya Allah akan meminta pertanggungjawaban mereka atas apa saja yang mereka urus/pelihara." (HR al-Bukhari dan Muslim)

Begitu juga dengan proses terpilihnya seseorang menjadi kepala daerah melalui pilkadal (pemilihan kepala daerah secara langsung) dalam sistem politik demokrasi sangat kontradiktif dengan terpilihnya seseorang menjadi kepala daerah dalam pemerintahan Khilafah Islamiyah.

Kepala daerah setingkat provinsi (wilayah) dalam negara khilafah disebut sebagai wali atau amir. Setiap wilayah dibagi dalam beberapa bagian dan setiap bagian disebut 'imalah. Setiap 'imalah dipimpin oleh seorang 'amil atau hakim. Berikutnya setiap 'imalah dibagi menjadi beberapa bagian administratif yang disebut qashabah (kota). Setiap qashabah dibagi dalam beberapa bagian administratif yang lebih kecil yang disebut hayyu (kampung/desa). Orang yang mengurusi qashabah dan hayyu masinhg- masing disebut mudir dan tugasnya adalah tugas administratif.

Seorang wali diangkat langsung oleh Khalifah, begitu juga kepala daerah di bawahnya. Wali tidak dipilih langsung oleh rakyat, apalagi oleh DPRD karena memang tidak ada DPRD dalam negara Khilafah. Penunjukkan secara langsung ini meniscayakan tidak adanya pemborosan uang ummat sebagaimana terjadi dalam Pilkada saat ini. Calon kepala daerah (wali/amir) dalam Khilafah tidak akan stress dengan besarnya dana pencalonan untuk kampanye atau menyuap rakyat agar mereka memilihnya sehingga mereka tidak perlu suntikan dana dari pihak lain (pengusaha). Calon kepala daerah juga tidak perlu menghambur-hamburkan uang sebagai kompensasi politik kepada partai-partai pendukungnya. Hal ini akan mencegah mereka berlaku korup dengan menyalahgunakan kekuasaan ketika menjabat.

Pengangkatan wali atau khalifah secara langsung ini didasarkan pada perilaku Rasulullah SAW. Sepanjang kepemimpinannya sebagai kepala negara, Rasulullah SAW telah mengangkat para wali untuk berbagai negeri. Beliau telah mengangkat Mu'adz bin Jabal menjadi wali di wilayah Janad, Ziyad bin Walid di wilayah Hadramaut dan Abu Musa al 'Asy ari di wilayah Zabid dan 'And. Mereka semua diberikan wewenang oleh Rasulullah SAW untuk memutuskan persengketaan. 
Mereka adalah orang-orang yang memiliki kelayakan (kemampuan dan kecakapan) untuk memegang urusan pemerintahan, orang-orang yang berilmu yang dikenal dengan ketakwaannya. Para wali Rasulullah SAW adalah orangorang yang amanah dan dapat melaksanakan tugas dengan baik dalam urusan yang menjadi kewenangannya dan dapat menghidupkan hati rakyat dengan keimanan dan keagungan negara.

Demikian juga masa-masa sepeninggal Rasulullah, para Khalifah mengangkat langsung para wali yang memiliki kelayakan untuk memegang urusan pemerintahan di wilayahnya. Keimanan dan ketakwaan para khalifah menjadikan mereka tidak akan mengangkat orang-orang yang tidak memiliki kelayakan karena sama saja dengan mengantarkan negara pada kehancuran. Oleh karena itu wali yang diangkat harus memenuhi syarat sebagai penguasa yaitu harus seorang Muslim, laki-laki, merdeka, baligh, berakal, adil dan memiliki kemampuan.

Meskipun kepala daerah dalam sistem khilafah tidak dipilih oleh rakyat, tetapi rakyat menentukan keberlanjutan jabatan wali dan 'amil itu. Jika rakyat, baik secara langsung atau melalui wakilnya, menunjukkan ketidaksukaan terhadap wali dan 'amil serta meminta diganti, maka khalifah atau kepala negara harus mengganti wali dan 'amil itu. Hal itu seperti yang terjadi ketika penduduk Bahrain mengadukan 'Ala' bin al-Hadhrami yang diangkat Rasul menjadi wali Bahrain, maka Rasul pun langsung memberhentikannya dan menggantinya dengan pejabat baru yang diridhai rakyat. Dengan sistem demikian, maka tidak perlu biaya yang karenanya meminimalkan peluang terjadinya korupsi demi mengembalikan biaya politik atau untuk memupuk modal proses politik berikutnya. Selain itu, rakyat akhirnya benar-benar bisa menjamin kelangsungan wali dan 'amil yang terus memperhatikan urusan rakyat dan berlaku baik terhadap rakyat. Dengan mekanisme demikian, apakah wali dan 'amil itu kerabat atau orang dekat khalifah atau bukan, tidak jadi masalah. Sebab mekanisme seperti itu akan memberikan jaminan yang lebih bagi terealisasinya penguasa daerah yang terus peduli dan memperhatikan rakyat, sekaligus bersih dan berlaku baik kepada rakyat.

Namun untuk mengantisipasi praktek korupsi para kepala daerah, khalifah juga perlu melakukan kebijakan sebagaimana di praktekan oleh Khalifah Umar bin Khaththab ra. kepada para pembesar negara, sipil atau militer, yang kaya dan penuh kemewahan yaitu dengan menanyakan dari mana mereka memperoleh hartanya. Lalu khalifah akan segera memerintahkan pemeriksa untuk meneliti berapa jumlah kekayaan si pejabat sebelum dan sesudah ia menduduki jabatan. Jika ada kelebihan maka ia harus dapat membuktikan dari mana harta itu diperoleh.

Jika ternyata diketahui bahwa pertambahan kekayaan pejabat tersebut diperoleh bukan dari hasil gaji resmi negara, maka disitalah harta itu dan dimasukkan ke kas negara (baitul maal). Harta yang oleh khalifah dianggap bukan hak milik pribadi, dinyatakan sebagai milik umat dan hak milik Allah. Sebab kekayaan demikian bukan tidak mungkin berasal dari hadiah dan sogok kepada pejabat itu untuk mendapatkan kemudahan bagi si penyogok, 
atau berasal dari pemerasan secara halus atas rakyat atau juga pengaruh kekuasaannya.

Demikianlah dengan penunjukkan kepala daerah langsung oleh khalifah akan menghemat uang negara dan mencegah terjadinya money politic begitu juga korupsi karena calon kepala daerah tidak perlu mengeluarkan dana yang besar untuk pencalonannya.

Selain itu, berkaitan dengan kebijakan keuangan dalam sistem khilafah juga menganut prinsip sentralisasi yang sangat berbeda dengan prinsip desentralisasi fiskal dalam otonomi daerah. Dalam sistem Khilafah, dana dari seluruh wilayah ditarik ke pusat, kemudian didistribusikan ke masing-masing daerah sesuai dengan kebutuhannya, bukan jumlah pemasukannya. Dengan kata lain, jika ada daerah yang sedang melakukan pembangunan dan membutuhkan dana besar, sementara boleh jadi pemasukannya tidak sebesar yang dibutuhkan, maka negara khilafah akan melakukan kebijakan subsidi silang.

Demikian juga jika suatu daerah membutuhkan dana besar baik karena ada bencana alam maupun urusan lain, sementara pendapatannya tidak sebesar yang dibutuhkan maka khilafah juga bisa melakukan kebijakan yang sama. Ini merupakan konsekuensi dari otoritas khalifah sebagai pemegang hak tabbani dalam penyusunan Anggaran Pendapatan dan Belanja Negara (APBN) khilafah.

Seperti halnya APBN maka APBD pun tidak dibuat setiap tahun karena tidak membutuhkan pembahasan dengan Majelis Ummat. Dalam penyusunan APBD yang terdiri dari pos pendapatan dan pengeluaran telah ditetapkan oleh syari'at, khalifah selaku kepala negara akan menyusun sendiri APBD sesuai dengan ketentuan syariat islam.

Dengan cara seperti ini, maka peluang penyelewengan keuangan di daerah akan tertutup karena hak penyusunan APBD bukan di tangan kepala daerah tapi khalifah yang akan mengalokasikan anggaran sesuai dengan keperluan daerah. Selain itu, tidak ada satu alokasi anggaran pun yang menguap atau tidak tepat sasaran sehingga pemerataan pembangunan pun bisa dilakukan dengan baik. Bahkan, tidak akan terjadi penumpukan kekayaan di daerah tertentu sementara yang lain kekurangan.

\section{Kesimpulan}

Berdasarkan pembahasan di atas, maka penulis menyimpulkan bahwa:

1. Penerapan otonomi daerah membawa dampak negatif yaitu semakin meningkatnya praktek korupsi yang dilakukan oleh pejabat di daerah. Ini membuktikan bahwa sistem yang ada lemah dan tidak bisa menyelesaikan berbagai masalah di negara ini termasuk korupsi.

2 Islam mempunyai metode yang khas untuk mencegah terjadinya korupsi di daerah (wilayah) yaitu dengan penerapan prinsip sentralisasi dimana kepala daerah (wali) ditunjuk langsung oleh khalifah dan pengelolaan keuangan yang berada di tangan khalifah sesuai ketetapan syariat. 


\section{Saran}

Setelah melalui serangkaian analisis dan pembahasan, maka penulis merumuskan sejumlah saran yaitu :

1. Korupsi hanya akan bisa dicegah dan diselesaikan dengan mengganti sistem yang ada dengan sistem Islam secara totalitas dalam seluruh aspek kehidupan;

2. Pelaksanaan sistem Islam dalam seluruh aspek kehidupan akan bisa menghasilkan aparat yang amanah dan bertakwa yang akan menjadi faktor pendukung keberhasilan penerapan sistem;

3. Islam memiliki seperangkat aturan hukum yang bisa membuat para pelaku korupsi berpikir seribu kali untuk melakukan tindak korupsi. Meski hukumnya hanya ta'zir, tapi pelaku korupsi memungkinkan dihukum maksimal yakni sampai hukuman mati.

\section{Daftar Pustaka}

Buyung, Bulizuar, 2002. Sistem Administrasi Negara Indonesia. Jakarta:

Universitas Terbuka.

Kaho, Josef Riwu, 2007. Prospek Otonomi Daerah Di Negara Republik Indonesia. Jakarta: PT Raja Grafindo Persada.

Kansil, CST \& Christine ST. Kansil, 2004. Pemerintahan Daerah Di Indonesia (Hukum Administrasi Daerah). Jakarta: Sinar Grafika.

Muluk, M.R Khairul. 2007. Desentralisasi dan Pemerintahan Daerah. Malang: Bayu media Publishing.

Nazir, M., 2003. Metode Penelitian. Jakarta: Ghalia Indonesia.

Widjaja, HAW, 2003. Titik Berat Otonomi Daerah. Jakarta: PT Raja Grafindo Persada. --------------, 2005. Penyelenggaraan Otonomi Di Indonesia. Jakarta: PT Raja Grafindo Persada.

Suhadak \& Nugroho Trilaksono, 2007. Paradigma Baru Pengelolaan Keuangan Daerah Dalam Penyusunan APBD Di Era Otonomi. Malang: Bayu media Publishing.

Tahrir, Hizbut, 2005. Struktur Negara Khilafah (Pemerintahan dan Administrasi). Jakarta: HTI-Press.

Media Massa www.media.indonesia.com www.mediaumat.com www.merdeka.com www.sayangi.com

airha's blog

repulika online 